\title{
Validity LKPD Based HOTS on Human Digestive System for Junior High School Grade VIII
}

\author{
Zulyusri $^{1 *}$ \\ ${ }^{1}$ Biology Department Math and Natural Science Faculty Universitas Negeri Padang Padang, Indonesia \\ *Corresponding author.zulyusri.ilyas@yahoo.com
}

\begin{abstract}
The curriculum 2013 requires students to have High Order Thinking Skills. Nowadays, however, The High Order Thinking Skills of students especially in Indonesia are still low. It is caused by many factors, such as the unavailability of HOTS-based worksheet at school. For instance, in SMPN 1 Padang, there is no worksheet such as HOTS-based LKPD that can increase High Order Thinking Skills of the student. The purpose of this research is to know the validity of LKPD based High Order Thinking Skills on Human Digestive System material for grade VIII. This research is a part of 4D Models which is the Development section. The data analyzed through quantitative analysis. The instrument of the data collection is using validation questionnaires. LKPD is validated by 2 lectures of Biology Department and a natural science teacher at SMPN 1 Padang. Based on the results of the study obtained, the validity of LKPD 90, 47\% with very valid category.
\end{abstract}

Keywords: Validity, Student Worksheet (LKPD), High Order Thinking Skills (HOTS)

\section{INTRODUCTION}

One of the media that can be used during learning activities is in the form of teaching materials namely Student Activity Sheets (LKPD). This LKPD will generate bensefits for both teachers and students. Learning media as one of the communication tools to convey messages, can stimulate students' thoughts, motivations and abilities so that they can encourage the learning and teaching process to be more effective and efficient (Arsyad; 2012, Usman \& Asnawir; 2002). At present, in education's field reality, many teachers in each school still use conventional student worksheets in the form of LKS that already exist from publishers, without any effort to plan, prepare the learning activities (Prastowo, 2012).

Learning process using LKPD can guide or show students to get concepts through experiments, summaries of material, including sentence statements, which interpret results from experimental data, predict the results of an experiment and forms of the exercise from the material being discussed (Mc Gregor, 2007). LKPD is a task that must be done by the students. LKPD usually contains instructions and steps for completing a task. An assignment ordered in the LKPD must be clear about the basic competencies that will be achieved (Muthoharoh et al., 2017). Besides being a learning media, LKPD also has other functions, namely: (1) an alternative for the teacher to direct the teaching process or introduce activities as learning activities; (2) helping the students to be more active in the learning process; (3) can arouse students' interest if the LKPD is arranged neatly, systematically, and easily understood by students so that it can attract the students 'attention; (4) can foster students' self-confidence and increase learning motivation and curiosity; and (5) can improve the ability of students to solve problems (Widjajanti, 2008). With the existence of LKPD, it is expected to be able to improve high-order thinking skills (HOTS) of the students.

HOTS itself is one of the demands of the 2013 curriculum that requires students to be able to think critically. HOTS are basically the ability to think at a higher level on the hierarchy of cognitive processes. The level of thinking refers to Bloom's taxonomy, which places thinking skills start from knowing until the evaluation stage (Ramos et al., 2013). According to Heong et al. (2011) HOTS is an important aspect of teaching and learning. HOTS practice is part of general skills that must be included in all subjects. Students with HOTS can learn, improve activities, and reduce learning difficulties. The fact is the students' HOTS in Indonesia are still in the low category (Susanti, et al., 2014). Based on the results of interviews and observations conducted by researchers towards science teachers at SMPN 1 Padang, Syofiani Evita, S.Pd., one of the causes of the low HOTS of students was the unavailability of teaching materials in the form of LKPD which guided students to think higher. Therefore, researchers feel that it is necessary to develop HOTS-based LKPD in science subjects, namely human digestive system for grade VIII.

HOTS in the LKPD developed are found in learning activities and task in the form of questions given to the students. The HOTS indicators on the LKPD activities are analyzing, creating, and evaluating. This is in accordance with the results of research by Kurniati, et al. (2016) that 
HOTS includes logic and reasoning capabilities (logic and reasoning), analysis, evaluation, creation, problem solving and decisions making (judgment). Zulyusri, et al. (2017) also found that from the results of the PISA trial conducted on junior and senior high school students participating in the science Olympiad at Sumatra Barat, Riau and Jambi levels at Universitas Negeri Padang on February $6^{\text {th }}, 2016$ showed unsatisfactory results. This is caused by students have not been trained in solving PISA questions so that they find it difficult to do PISA questions.

The material discussed in HOTS -based LKPD developed was material on the Human Digestive System. This material is found in $\mathrm{KD} 3.5$. In this $\mathrm{KD}$ students are required to have analytical skills which are one of the indicators in high-level thinking skills. In addition, based on the results of the author's observation, the teacher still uses the lecture method and question and answer while explaining the material in the class. Therefore, a teaching material in the form of HOTS -based LKPD has been developed in the material for Human Digestive System for class VIII, but its validity level is yet unknown.

\section{MATERIAL AND METHODS}

This research is the development stage of the 4D model research. In this study an evaluation of the validity of the products developed was HOTS -based LKPD on human digestive system material for class VIII SMP. Validation is done by discussing LKPD to experts, namely 2 Biology lecturers, FMIPA UNP and 1 natural science teacher at SMPN 1Padang.

In order to obtain a valid LKPD, the validity assessment of HOTS -based LKPD was conducted using the validity questionnaire instrument LKPD validated by 2 Biology lecturers from FMIPA UNP and 1 teacher at SMP 1 Padang. The aspects assessed in the validity test are content feasibility, HOTS components, linguistic components, presentation components, and graphic components. The criteria of validity assessment are modified from Purwanto (2009) as follows.

$$
\begin{aligned}
& 90 \%-100 \%=\text { Very valid } \\
& 80 \%-89 \%=\text { Valid } \\
& 60 \%-79 \%=\text { Quite Valid } \\
& 0 \%-59 \%=\text { Invalid }
\end{aligned}
$$

\section{RESULT AND DISCUSSION}

\section{Research Finding}

Based on the validity test that has been done by the validator, it is known that HOTS-based LKPD is stated to be very valid. Validation carried out covers five aspects, namely content feasibility, HOTS components, linguistic components, presentation components, and graphic components. The results of the HOTS -based LKPD validity test can be seen in Table 1 .

Table 1. Results of HOTS-based LKPD Validity Test

\begin{tabular}{llll}
\hline No & Aspects & $\begin{array}{l}\text { Validity } \\
\text { Values (\%) }\end{array}$ & Criteria \\
\hline 1. & Content Feasibility & 91,66 & Very Valid \\
2. & HOTS Components & 91,66 & Very Valid \\
3. & Linguistics & 88,33 & Valid \\
4. & Components & 94,04 & Very Valid \\
5. & Presentation & 86,66 & Valid \\
& Components & & \\
& Graphic Components & Very Valid \\
\hline Average & $\mathbf{9 0 , 4 7}$ & \\
\hline
\end{tabular}

The results of validity in Table 1 show an average value of $90.47 \%$ with very valid criteria. This shows that HOTSbased LKPD developed has been very valid, both from the aspects of feasibility, content, language, presentation, and graphics. In the validation process, the LKPD has been revised several times based on the suggestions given by the validator. This can be seen in Table 2 


\begin{tabular}{|c|c|c|c|}
\hline No & Validators & Advice & Follow- Up \\
\hline 1. & Dra. Helendra, M.S. & $\begin{array}{l}\text { a. Change the } \\
\text { background of the } \\
\text { cover image } \\
\text { b. Change the writing } \\
\text { color on the cover } \\
\text { c. Show HOTS identity } \\
\text { on LKPD } \\
\text { d. Slide the bar on the } \\
\text { right so that the } \\
\text { writing is not too } \\
\text { close to the edge } \\
\text { frame of the LKPD } \\
\text { e. Refine the writing } \\
\text { according to the } \\
\text { Indonesian Spelling } \\
\text { (EBI) procedure } \\
\text { f. Writing on the table is needed } \\
\text { to be tidied up using the left } \\
\text { alignmen } \\
\text { g. Fix proportion of image size } \\
\text { h. Change the image with the } \\
\text { source obtained from the } \\
\text { author's personal document }\end{array}$ & $\begin{array}{l}\text { a. The background of the cover image has been changed or } \\
\text { edited with the Adobe Photosop application. } \\
\text { b. The writing color of the cover is changed from black to dark } \\
\text { purple and red } \\
\text { c. HOTS identity has been displayed in the LKPD title } \\
\text { d. The bar is shifted and is spaced between the writing and the } \\
\text { edge frame of the LKPD } \\
\text { e. The writing system has been fixed, for example } \\
\text { punctuation, etc. } \\
\text { f. The writing on the table has been fixed and uses left } \\
\text { alignment } \\
\text { g. The proportion of image size has been fixed } \\
\text { h. The image has been replaced with the author's document } \\
\text { source }\end{array}$ \\
\hline 2. & Drs. Ardi M.Si & $\begin{array}{l}\text { a. The point column for the } \\
\text { answer field is needed to be } \\
\text { tidied up } \\
\text { b. Replace cover images with } \\
\text { relevant images, according to thec } \\
\text { material that being discussed in } \\
\text { the LKPD } \\
\text { c. Note the decapitation } \\
\text { according to the EBI } \\
\text { Remove the expression column, } \\
\text { because it is } \\
\text { Ambiguous }\end{array}$ & $\begin{array}{l}\text { a. The point column for the answer field has been fixe } \\
\text { b. The front cover image is replaced with an image that is more } \\
\text { relevant to the material being discussed in the LKPD } \\
\text { c. Decapitation has been fixed } \\
\text { d. Expression column removed }\end{array}$ \\
\hline 3. & Taufik Hendra, S.Pd & $\begin{array}{l}\text { a. Use opening } \\
\text { sentences to bring up } \\
\text { student perceptions at } \\
\text { the beginning of the } \\
\text { summary material } \\
\text { b. Show pictures / } \\
\text { illustrations on } \\
\text { several reviews of } \\
\text { objective question } \\
\text { competencies to train } \\
\text { students' thinking } \\
\text { skills } \\
\text { c. Reduce the number of } \\
\text { questions that have } \\
\text { not been HOTS }\end{array}$ & $\begin{array}{l}\text { a. The opening sentence is displayed at the beginning of the material } \\
\text { summary to bring out the students' perceptions of the material to be } \\
\text { learned } \\
\text { b. } \\
\text { c. Pictures / illustrations added } \\
\text { that require students' high-level thinking skills }\end{array}$ \\
\hline
\end{tabular}




\section{DISCUSSION}

Validation is the process of requesting approval or endorsement of the suitability of a product with the needs so that the products are declared suitable and appropriate for learning (Ahsyar, 2011). According to Oktaviyanthi, and Dahlan (2018) the validity of the LKPD is needed to obtain a valid LKPD that is in accordance with the desired standards. Validation is done by several experts / experts, such as linguists. In the validation stage, the products that have been designed are assessed by experts whether the LKPD activities developed are more effectively used than the previous LKPD or not. If it is not yet valid, then the LKPD developed will be revised until it is declared valid by the validator (Wibawa et al. 2018).

The aspects assessed in the validity test are:

1. Content Feasibility Aspect

According to Yulianti (2014), an LKPD is declared valid

if a summary of the material contained in the LKPD is in accordance with the indicators and learning objectives. Judging from the aspect of content feasibility, HOTS-based LKPD are stated to be very valid. This shows that the material on HOTSbased LKPD is in accordance with the demands of the Curriculum 2013 Revised 2016 and is in accordance with the demands of Core Competencies (KI) and Basic Competencies (KD) outlined through Indicators of Competency Achievement (IPK). According to Putra, et al. (2018) LKPD that has been valid in terms of the content feasibility aspect, can be concluded that the LKPD used has met the principle of depth and accuracy of the material. The material contains facts, concepts, principles, and procedures that are relevant to the learning objectives and presented systematically with regard to the material sequence. Very valid criteria also show that the truth of the material substance at the LKPD is good.

\section{HOTS Aspect.}

The HOTS aspect contains statements that indicate whether this LKPD has specifically contained HOTS in it or not. According to Fanani, et al. (2018) the development of learning that pays attention to HOTS is adjusted to Bloom's taxonomy, HOTS started from remembering, understanding, applying to analyzing, evaluating, and creating. Based on the results of the validity test, it is known that the HOTS component contained in the LKPD is stated to be very valid. This shows that the HOTS indicator already exists in the LKPD developed.

3. Linguistics Aspect.

According to Setyawati, \& Suliyanah (2018) LKPD that

has the validity of linguistic aspects is characterized by the use of Indonesian language correctly and communicative language so that it is easily understood by students. Based on the results of the validity test, HOTS-based LKPD in terms of language aspects were declared valid by the validator. Moreover, Sulviana (2016) states that LKPD is valid in terms of linguistic aspects means that the LKPD uses simple, clear, easy to understand sentences, the language used is communicative, and in standard form. This shows that HOTS-based LKPD does not use ambiguous language. HOTS-based LKPD can also be said to be clear, simple, communicative and easy to understand.

4. Presentation Component Aspect.

The presentation aspects include the font size and type on the LKPD, the use of colors, and the emphasis on writings that are considered necessary (Revita, 2017). In addition,

Faridah et al. (2014) states LKPD is declared valid in terms of presentation component aspects if the LKPD has conformity to the appearance of the LKPD cover with the content of the material, the complete contents of the LKPD, and the suitability of the letter type and size used in the LKPD. Based on the results of the validity test, it is known that the HOTS-based LKPD developed was declared very valid by the validator from the aspect of the presentation component. This means that HOTSbased LKPD has used clear letter writing, a complete content section, and there is an emphasis on writing that is deemed necessary.

\section{Graphic Component Aspect.}

According to Maharani (2015), the LKPD which was declared valid from the graphic aspect meant that the LKPD had an attractive appearance, with variations in appearance through images, colors and letters. Whereas Hamimi, et al. (2014) states that LKPD which is declared valid from the graphic aspect is seen from the LKPD format, the design of the LKPD cover, and the photos / images included in LKPD are relevant. Based on the results of the validity test, it is known that HOTS-based LKPD developed has valid criteria in terms of graphic components aspects. This means that HOTS-based LKPD has an attractive appearance, both from the cover design, image, color, letters, and format used as well as relevant photos / images.

The evaluation of the validator on the HOTS-based LKPD developed showed that the LKPD was appropriate to be used as teaching material for students to use in the learning process. This is in accordance with Arsih (2017) research which states that valid validation results indicate that teaching materials can be used as teaching materials in the learning process.

\section{CONCLUSION}

HOTS-based LKPD developed in the material Human Digestive System for grade VIII Junior High School students, has met very valid criteria by the validator by assessing the average validity of $90.47 \%$.

\section{REFERENCES}

[1] Ahsyar, Rayandra. 2011. Kreatif Mengembangkan Media Pembelajaran. Jakarta: Gaung Persada Press.

[2] Arsih, F., Fitri, R dan Yogica, R. 2017. Validitas Panduan Praktikum Fisiologi Hewan Berbasis Keterampilan Proses Sains untuk Mahasiswa Jurusan Biologi Universitas Negeri Padang. Bioeducation Journal, Vol. I, No. 2.

[3] Arsyad,Nurdin.2012.ModelPembelajaran Menumbuhkembangkan Kemampuan Metakognitif. Makassar. Pustaka Refleksi.

[4] Asnawir \& M. Basyirudin Usman. Media Pembelajaran. 2002. Jakarta: Ciputat Press.

[5] Depdiknas. 2008. Panduan Pengembangan Bahan Ajar. Jakarta: Direktorat Jenderal Manajemen Pendidikan Dasar dan Menengah.

[6] Fanani, Achmad., Kusmaharti, Dian. 2018. Pengembangan Pembelajaran Berbasis HOTS di Sekolah Dasar Kelas V. Jurnal Pendidikan Dasar. Vol. 9, No. 1.

[7] Faridah, Listia Adhayul., Purnomo, Tarzan., Ambarwati, Reni. 2014. Pengembangan Ensiklopedia dan LKS Invertebrata Laut untuk Pembelajaran Biologi. Berkalah Ilmiah Pendidikan Biologi. Vol. 3, No. 3. 
[8] Hamimi, Erti., Susantini, Endang., Ambarwati, Reni. 2014. Pengembangan LKS Berorientasi Model 5E Berbahasa Inggris pada Subpokok Bahasan Vertebrata. Berkalah Ilmiah Pendidikan Biologi. Vol. 3, No. 3.

[9] Heong, YM., Othman, WB., Yunos, JBM. 2011. The Level of Marzano Higher Order Thinking Skills among Technical Education Students. International Journal of Social Science and Humanity. Vol. 1, No. 2.

[10] Kurniati, D., Harimukti, R., Jamil, NA. 2016. Kemampuan Berpikir Tingkat Tinggi Siswa SMP di Kabupaten Jember dalam Menyelesaikan Soal Berstandar PISA. Jurnal Penelitian dan Evaluasi Pendidikan. Vol. 20, No. 2.

[11] Maharani, Deffy. 2015. Pengembangan LKS Multirerpesentasi Berbasis Pemecahan Masalah pada Pembelajaran Fisika di SMA. Jurnal Pembelajaran Fisika, Vol. 4, No. 3.

[12] McGregor, D. 2007. Developing Thinking Developing Learning. Poland: Open University Press.

[13] Muthoharoh, M., Kirna, IM., Indrawati, Gusti Ayu. 2017. Penerapan Lembar Kerja Peserta Didik (LKPD) Berbasis Multimedia untuk Meningkatkan Motivasi dan Hasil Belajar Kimia. Jurnal Pendidikan Kimia Indonesia. Vol. 1, No. 1.

[14] Oktaviyanthi, R., Dahlan, J. A. 2018. Developing Guided Worksheet for Cognitive Apprenticeship Approach in Teaching Formal Definition of The Limit of a Function. IOP Conference Series: Materials Science and Engineering, Vol. 335, No. 1.

[15] Prastowo, Andi. 2012. Panduan Kreatif Membuat Bahan Ajar Inovatif. Yogyakarta: Diva Press.

[16] Purwanto, Ngalim. M. 2009. Prinsip-prinsip dan Teknik Evaluasi Pengajaran. Bandung: Remaja Rosdakarya.

[17] Putra, Aan., Syarifuddin, Hendra., Zulfah. 2018. Validitas Lembar Kerja Peserta Didik Berbasis Penemuan Terbimbing dalam Upaya Meningkatkan Pemahaman Konsep dan Kemampuan Penalaran Matematis. Edumatika Jurnal Riset Pendidikan Matematika. Vol. 1, No. 2.

[18] Ramos, JLS., Dolipas, BBS., Villamor, BB. 2013. Higher Order Thinking Skills and Academic Performance in Physics of College Students: A Regresssion Analysis. International Journal of Innovative Interdisciplinary Research. Vol. 4.

[19] Revita, Rena. 2017. Validitas Perangkat Pembelajaran Matematika Berbasis Penemuan Terbimbing. Suska Journal of Mathematics Education, Vol. 3, No. 1.

[20] Setyawati, I. Neny., Suliyanah. 2018. Pengembangan Lembar Kerja Peserta Didik (LKPD) Berbasis Guided Discovery untuk
Melatihkan Keteramilan Proses Sains Peserta Didik pada Materi Getaran Harmonis di MA Negeri Sidoarjo. Jurnal Inovasi Pendidikan Fisika, Vol. 7, No. 2.

[21] Sulviana, Fitria. 2016. Pengembangan LKPD IPA Guided Inquiry untuk Meningkatkan Produk Kreativitas Peserta Didik SMP/MTs. Jurnal Pendidikan Matematika dan Sains. Vol. 4, No. 1.

[22] Susanti, E., Darhim, YSKJS. 2014. Computerassisted Realistic Matemathics Education for Enhancing Student's Higher-Order Thinking Skills (Experimental Study in Junior High School in Palembang, Indonesia). Journal of Education and Practice. Vol. 5., No. 18

[23] Trianto. 2010. Model Pembelajaran Terpadu. Jakarta: Bumi Aksara.

[24] Wibawa SC., Cholifah, R., Utami, AW., Nurhidayat, AI. 2018. Creative Digital Worksheet Base on Mobile Learning. IOP Conference Series: Materials Science and Engineering, Vol. 228, No. 1.

[25] Widjajanti, E.LFX. 2008. Kualitas Lembar Kerja Siswa. Makalah disajikan dalam Kegiatan Pengabdian Masyarakat dengan Judul "Pelatihan Penyusunan LKS Mata Pelajaran Kimia Berdasarkan Kurikulum Tingkat Satuan Pendidikan Bagi Guru SMK/MAK, di Universitas Negeri Yogyakarta

[26] Yulianti, Evi. 2014. Validitas LKS Pengamatan Berdasarkan Pendekatan Saintifik pada Sub Pokok Bahasan Angiospermae. Ejournal Unesa, Vol. 3, No. 3.

[27] Zulyusri., R. Sumarmin., dan Miswati. 2017. Pengembangan Soal Biologi Berbasis Literasi Sains untuk Siswa SMA Kelas X Semester 1. Bioeducation Journal, Vol. 1, No. 1. 